\title{
MINERAL RESOURCE POTENTIAL OF THE WONDER MOUNTAIN ROADLESS AREA, MASON COUNTY, WASHINGTON
}

By

\author{
S. E. Church, J. G. Frisken, and R. W. Tabor \\ U.S. Geological Survey \\ and
}

S. R. Iverson, U.S. Bureau of Mines

\section{STUDIES RELATED TO WILDERNESS}

Under the provisions of the Wilderness Act (Public Law 88-577, September 3, 1964) and related acts, the U.S. Geological Survey and U.S. Bureau of Mines have been conducting mineral surveys of wilderness and primitive areas. Areas officially designated as "wilderness," "wild," or "canoe" when the act was passed were incorporated into the National Wilderness Preservation System, and some of them are presently being studied. The act provided that areas under consideration for wilderness designation should be studied for suitability for incorporation into the Wilderness System. The mineral surveys constitute one aspect of the suitability studies. The act directs that the results of such surveys are to be made available to the public and be submitted to the President and the Congress. This report discusses the results of a mineral survey of the Wonder Mountain Roadless Area (U.S. Forest Service Number 06086), Olympic National Forest, Mason County, Wash. Wonder Mountain Roadless Area was classified as a further planning area during the Second Roadless Area Review and Evaluation (Rare II) by the U.S. Forest Service, January 1979.

\section{MINERAL RESOURCE POTENTIAL SUMMARY STATEMENT}

The results of geological, geochemical, and mining activity and production surveys in the Wonder Mountain Roadless Area indicate low potential for manganese resources. Deposits are small, pod-shaped bodies (about 12,000 tons of identified resources), and the manganese occurs primarily as bementite (a manganese silicate), which is difficult to refine. Currently, there is one lode claim for manganese in the roadless area, along Copper Creek. There is no indication of any potential for other metallic, nonmetallic, or energy resources in the area.

\section{INTRODUCTION}

High mountain ridges with rugged outcrops of basalt characterize the Wonder Mountain Roadless Area in the southeastern Olympic Mountains (fig. 1). The area adjoins Olympic National Park to the north, Lake Cushman Reservoir to the east, and heavily logged areas within Olympic National Forest to the south and west. It covers 9,468 acres of the Olympic National Forest. Access to the roadless area is through Hoodsport on U.S. Highway 101. A paved road leads northwest to Staircase Rapids in Olympic National Park at the head of Lake Cushman. The south and west sides of the area are accessible by logging roads along the South Fork of the Skokomish River.

\section{GEOLOGY}

The Olympic Mountains comprise two geologic terranes: (1) a peripheral belt of Eocene to Miocene basaltic volcanic rocks and sedimentary rocks, which wraps partly around (2) a core of mostly sedimentary rocks of about the same age (Tabor, 1982). The fossiliferous peripheral rocks are faulted and folded, but generally the stratigraphy within structural blocks is preserved. Core rocks of the Olympic Mountains are highly deformed, mostly unfossiliferous, and, in the eastern part, are penetratively sheared and metamorphosed. Beds in the core rocks dip predominantly eastward, but units become younger to the west. The core rocks were stacked and thrust under the peripheral rocks during plate-margin convergence (Tabor and Cady, 1978a). The deformation in the eastern part of the Olympic Mountains culminated during the Oligocene about 29 million years ago, but local faulting and folding continued at least into the Miocene (Tabor, 1972). Tabor (1982) has prepared a detailed geologic map of the roadless area, and a simplified version of his geologic map is used as a base in figure 2. Most of the Wonder Mountain Roadless Area is in the peripheral belt southwest of the Olympic Mountain core rocks. The rocks of the peripheral belt are divided into two units: the Crescent Formation and the rocks of Blue Mountain. The Crescent Formation is lower(?) and middle Eocene (Rau, 1964, p. G4; 1967, p. 11) oceanic basalt, pillow basalt, and breccia, as well as diabase, gabbro, minor interbedded sedimentary rocks, and red, manganiferous argillite 


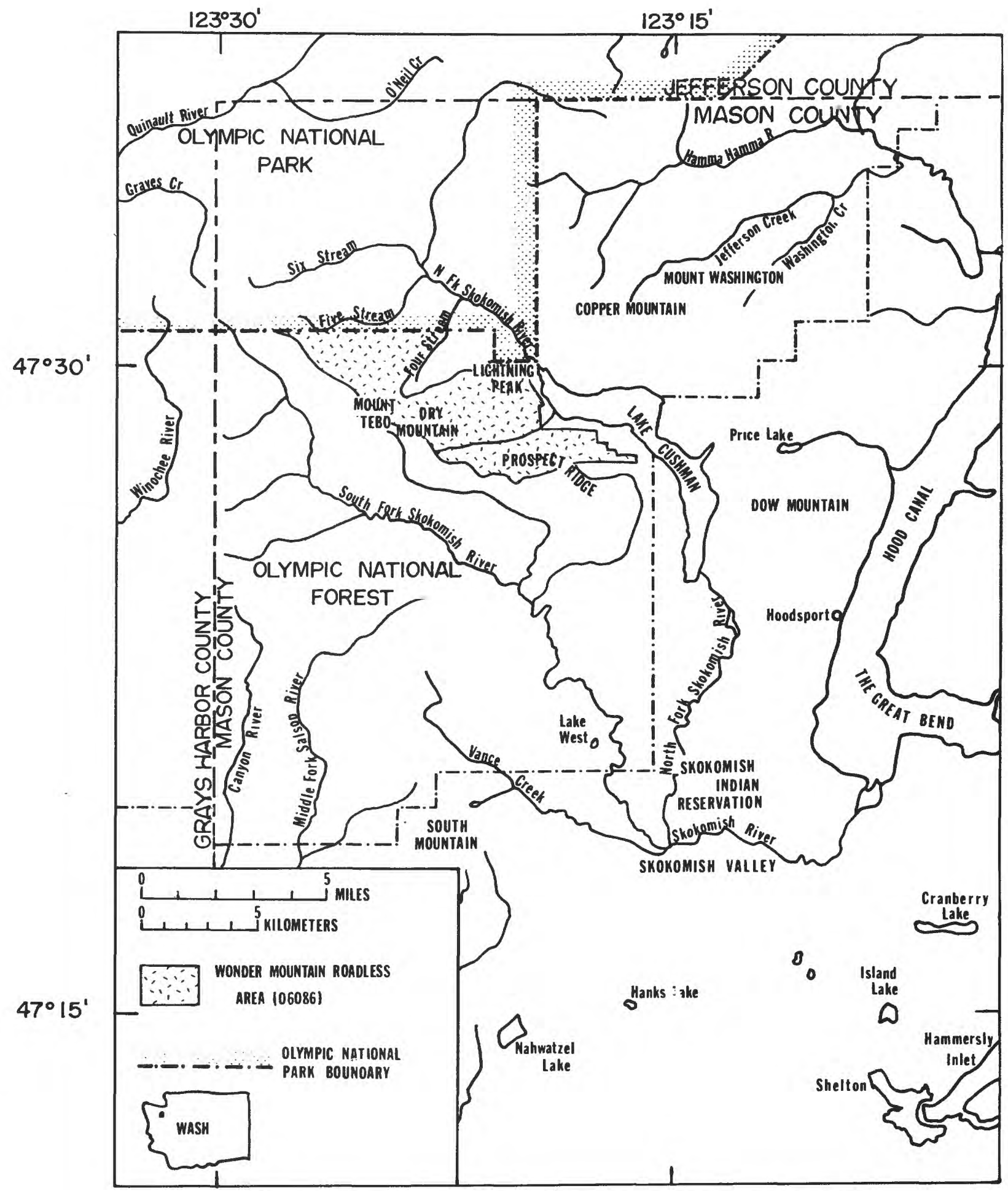

Figure 1.-Index map showing the location of the

Wonder Mountain Roadless Area (06086) on the southeastern flank of the Olympic Mountains, Mason County, Wash. 
and limestone. The lava erupted mostly from the ocean floor and formed seamounts fairly near the continent ( $\mathrm{Cady}, 1975$, p. 579-580). The upper part of the Crescent Formation bears shallow marine foraminifera and locally has columnar jointing, which suggests the seamounts reached sea level. The distinctive lithologic units of the Crescent Formation are subdivided on the simplified geologic base (fig. 2).

Underlying the Crescent Formation, and locally interfingering with it, are marine turbidites, rich in volcanic clasts, and dark argillite. These rocks are best exposed on Blue Mountain and are informally referred to as the sandstone and argillite of Blue Mountain. In the roadless area, these rocks are more strongly deformed than is most of the Blue Mountain unit north of the roadless area, but the deformation is less intense than that seen in the core rocks.

Within the roadless area, a zone of rocks rich in red, limy argillite and red limestone contains the manganese mineralization. This zone occurs at the base of the Crescent Formation and extends into a zone of interfingering basaltic rocks and sedimentary rocks of the Blue Mountain unit. All of the known manganese prospects of the roadless area are in this red zone; a few red argillite and limestone lenses crop out in the Crescent Formation south of the red zone.

Olympic core rocks crop out only in a small part of the Wonder Mountain Roadless Area. Along much of its length, the contact between the peripheral rocks and core rocks is marked by faulting, truncation of structure, and (or) a change in sandstone lithology (Cady and others, 1972a, b; Tabor and others, 1972; Tabor and Cady, 1978b, p. 5). In the vicinity of the roadless area, the contact is marked by the change frow the mildly deformed rocks of the peripheral belt to the highly deformed core rocks, which are broken and show a strong penetrative cleavage. No fossils have been found in the core rocks of the roadless area; however, fossils of a late Eocene fauna have been found within the core rocks to the north ( $\mathrm{C}$ ady and others, 1972b). Although, within the roadless area, the basaltic rocks of the Olympic core are mostly indistinguishable from the Crescent Formation, the basaltic rocks of the Olympic core do not contain red argillite, limestone, or concentrations of manganese minerals.

There are about 150 known deposits of manganiferous rocks in a 125-mi belt around the north, east, and south sides of the Olympic Mountains. These deposits have been described by several authors (Park, 1942, 1946; Magill, 1960). Roy (1981, p. 272-277) classified the deposits as volcanogenic-sedimentary type. Park (1946, p. 318) concluded that the deposits were the result of direct chemical precipitation of oxides from seawater. Work by Sorem and Gunn (1967, p. 45), as well as experimental data (summarized by Roy, 1981, p. 82-87), substantiates the mechanism of precipitation of $m$ anganese oxides from seawater as a function of Eh and $\mathrm{pH}$. Basically, the manganese deposits of the Wonder Mountain Roadless Area are small, lenticular bodies that are associated with the deposition of red limestone, siltstone, and some jasper. These zones show irregular stratigraphic relationships with the underlying basalts of the Olympic core and with the overlying Crescent Formation of the peripheral belt (Tabor, 1982). Garrison (1973, p. 590-592) noted that the deposition of manganeserich zones is strongly dependent on the local relief in the basin, as well as on the currents transporting the sediments. Volcaniclastic sediments accumulate near zones of active volcanism. Away from these areas, in quiet water, chemical precipitates, along with pelagic ooze, settle on cooled pillow basalt and are swept by currents and gravity in to topographic lows and into open spaces in the underlying basalts. Garrison (1973, p. 580-592) also considered this ponding of sediments and the subsequent postdepositional volcanic activity (the Crescent basalts) that disrupted the manganese-oreformation process to be the major reasons for the lenticular and disrupted nature of the deposits.

\section{GEOCHEMISTRY}

During the summer of 1981, a geochemical reconnaissance of the Wonder Mountain Roadless Area was conducted. Forty stream-sediment samples and 44 panned-concentrate samples from stream sediments were collected from first- and second-order streams draining the roadless area. Twenty-two rock samples were taken to characterize chemically the volcanic and sedimentary units cropping out in the roadless area and to determine the chemical constituents of the manganese-rich zones. The rock samples were crushed and pulverized, and the stream sediments were sieved to minus -80 mesh and pulverized. The pannedconcentrate samples were sieved to minus $-30 \mathrm{mesh}$, and a heavy-mineral fraction was separated with bromoform (specific gravity $>2.8$ ). A nonmagnetic, heavy-mineral concentrate was then produced using a Frantz Isodynamic Magnetic separator ${ }^{1}$. These concentrates were examined under the microscope for mineral identification and then pulverized. All three sample media were analyzed for 31 elements by a sixstep, semiquantitative emission-spectrographic technique routinely used by the U.S. Geological Survey (Grimes and Marranzino, 1968). The analytical and statistical data have been published (Church and others, 1982), and a geochemical interpretation is given by Frisken and others (in press).

The geochemical investigations reveal a suite of elements from the nonmagnetic, heavy-mineral fraction of panned-concentrate samples from stream sediments (barium, manganese, copper, cobalt, nickel, vanadium, and lead) that reflects the sedimentary origin of the manganese deposits of the Olympic Peninsula (Frisken and others, in press). Geochemical data for drainage basins draining only basaltic terrane do not indicate a potential for manganese deposits. However, geochemical data from drainage basins having outcrops of the Blue Mountain unit show anomalous metal concentrations for several of the elements given above (Frisken and others, in press). Favorable areas for manganese deposits are those underlain by the sedimentary rocks (fig. 2). These areas are in the drainage basins of Elk Creek and Copper Creek on the east side of the roadless area, and of Steel Creek on the west side of the roadless area (see fig. 2). Fragments of red limestone are abundant in these drainages. Analytical data for manganese-rich zones are given in table 1. Samples

\footnotetext{
${ }^{1}$ Any use of brand names is for descriptive purposes only and does not imply endorsement by the U.S. Geological Survey.
} 


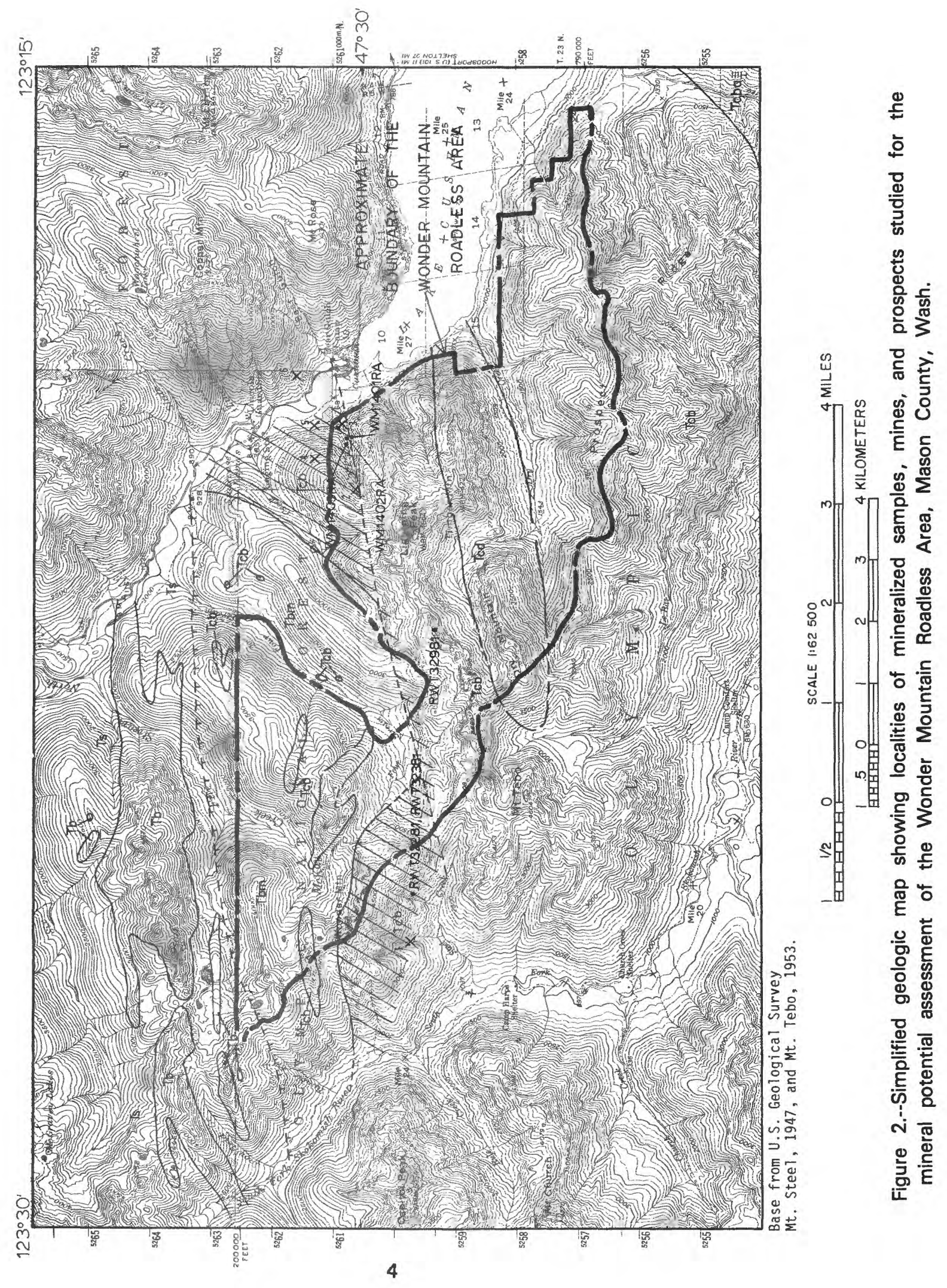



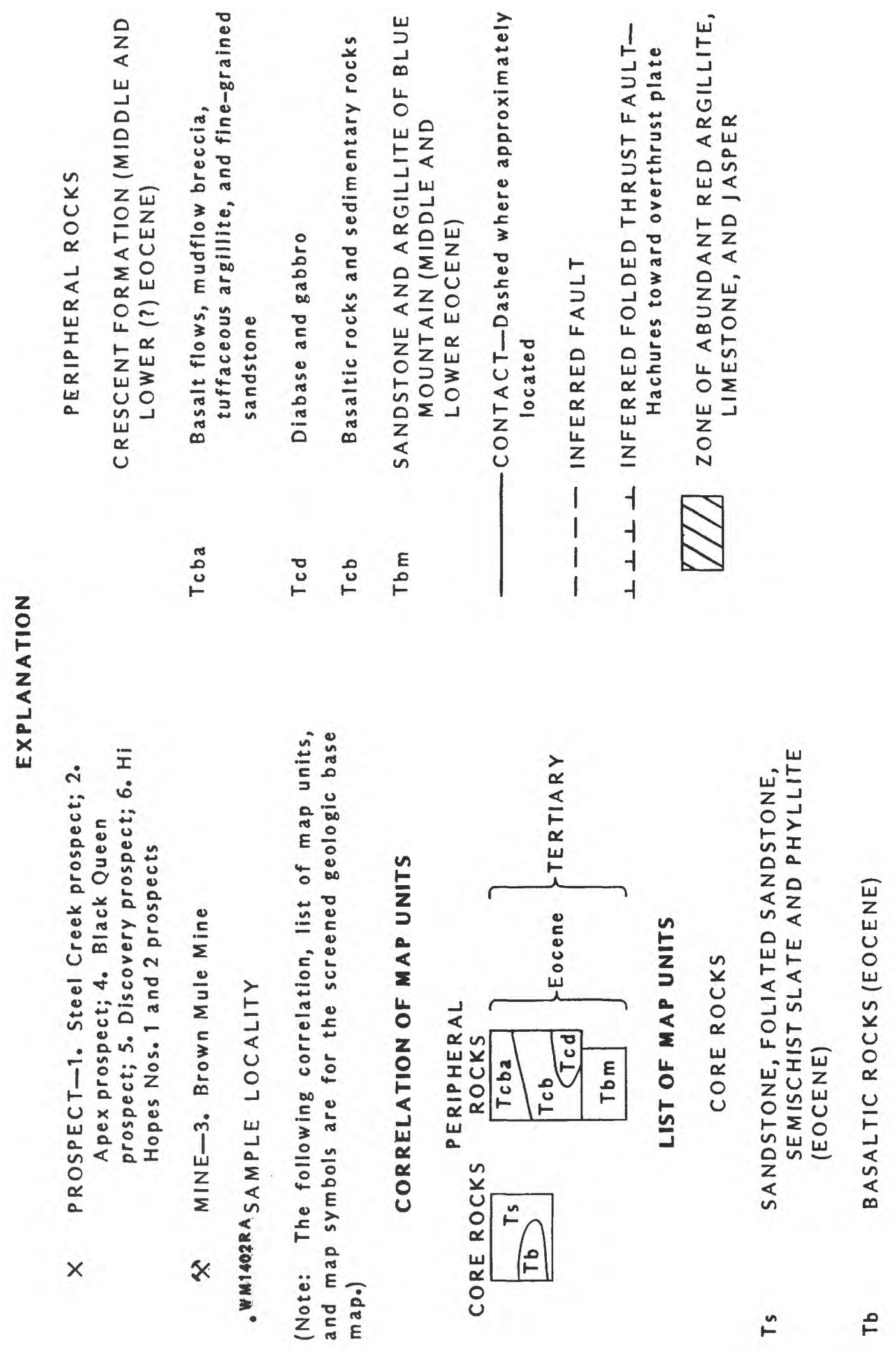
of the red limestone-argillite unit also contain high concentrations of manganese.

Table 1.-Analytical results ${ }^{1}$ from ores sampled within the Wonder Mountain Roadless Area, Mason County, Wash.

[All results given in parts per million $(\mu \mathrm{g} / \mathrm{g}$ ); $\mathrm{N}$, not detected at a given value; $>$, concentration greater than value given]

\begin{tabular}{|c|c|c|c|}
\hline Element & $\begin{array}{c}\text { Copper Creek } \\
\text { drainage }\end{array}$ & $\begin{array}{l}\text { Elk Creek } \\
\text { drainage }\end{array}$ & $\begin{array}{l}\text { Steel Creek } \\
\text { drainage }\end{array}$ \\
\hline $\mathrm{V}-$ & $100-150$ & 1,500 & $150-200$ \\
\hline $\mathrm{Mn}-$ & 5,000 & $>5,000$ & $>5,000$ \\
\hline $\mathrm{Co}$ & N5-20 & 1,000 & $30-50$ \\
\hline $\mathrm{Ni}-$ & $70-200$ & 150 & $100-300$ \\
\hline $\mathrm{Cu}$ & $30-200$ & 3,000 & $10-100$ \\
\hline $\mathrm{Mo}$ & N5 & 20 & N5-15 \\
\hline $\mathrm{Pb}-$ & N10-30 & N10 & N10 \\
\hline $\mathrm{Sr} \longrightarrow$ & $100-5,000$ & N100 & N100-300 \\
\hline $\mathrm{Ba}-$ & $200->5,000$ & 150 & $100-200$ \\
\hline
\end{tabular}

\section{MINING DISTRICTS AND MINERALIZATION}

The Wonder Mountain Roadless Area is within the indefinite boundaries of the Lake Cushman, Mount Tebo, and Wonder Mountain mining districts. Prospecting for manganese and copper ore in these districts began in the late 1800's. In 1890 James McReavy organized the Mason County Mining and Development Company to prospect for iron and copper ore in the Lake Cushman area (Overland, 1981, p. 16), and in 1895 the Discovery claims on Copper Creek were located. Manganese was discovered in the Lake Cushman area in 1903. In 1911 Frank Wonder discovered manganese and located several claims near Steel Creek; west of the roadless area. According to Pardee (1921, p. 237), in 1916 a shipment of lode ore was excavated from shallow pits and trenches at the Triple Trip (Brown Mule) Mine. During World War I, Robert Rowe shipped manganese ore from the Lake Cushman mines (probably from the Black and White Mine $4 \mathrm{mi}$ north of the roadless area) to his smelter in Tacoma, Wash. The 5-ton shipment assayed $0.40 \mathrm{oz}$ silver per ton, 7.85 percent copper, 3.2 percent iron and 65 percent insoluble residue (Magill, 1960, p. 64). When the war ended, demand for manganese decreased, and the claims and plans to build a smelter near Copper Creek were abandoned (Overland, 1981, p. 17).

The Crescent Mine, about 35 mi northwest of the roadless area, in Clallam County, produced about
46,000 tons of manganese ore, primarily haus mannite $\left(\mathrm{Mn}_{3} \mathrm{O}_{4}\right)$, and accounted for 98 percent of the total manganese production from the Olympic Peninsula (Magill, 1960, p. 76). Six prospects located within or adjacent to the roadless area were also examined (see table 2). The Apex prospect and the Brown Mule Mine are in the Wonder Mountain Roadless Area, whereas the Steel Creek, Black Queen, Discovery, and Hi Hope prospects are just outside the roadless area boundary (see fig. 2). Salient geologic features of these prospects are given in table 2.

Sorem and Gunn (1967) conducted a detailed study of the mineralogy of ore samples from seven typical manganese deposits of the Olympic Peninsula. In samples from the Brown Mule deposit, they identified the following: alleghanyite, bementite, johannsenite, neotocite, rhodonite, and tephroite (all manganese silicates); hausmannite, jacobsite, and rancieite (all manganese oxides); and rhodochrosite, the manganese carbonate. Other minerals identified were quartz, calcite, barite, copper, cuprite, hematite, grossularite, and hydrogrossular. This suite is typical of the region, and typical ore samples are composed of a mixture of very fine grains of several of these minerals. Lithification and contact metamorphism from intruding and overriding basaltic lavas may have modified the original chemical compounds, perhaps creating some of the silicate minerals. There is, however, little evidence that the suite of minerals has changed much since deposition. Bementite is the most abundant manganese mineral. Supergene mineralization is not significant in most deposits. Sulfides and sulfates, including alabandite, barite, cinnabar, chalcopyrite, and pyrite, have been described from many of the deposits, but nowhere are these dominant ore-zone minerals.

Three placer claims and 117 lode claims have been recorded in the roadless area since 1892. At present, there is one lode claim for manganese in the roadless area near the boundary, on Copper Creek.

\section{ASSESSMENT OF MINERAL RESOURCE POTENTIAL}

About 12,000 tons of manganese resources occur in or near the Wonder Mountain Roadless Area. As far as known, the manganese deposits are small, podshaped lenses (Park, 1942, P. 435; Roy, 1981, p. 87); therefore, the potential for significant manganese resources is low. Geologic conditions favorable for the occurrence of manganese deposits are limited to the belts of sedimentary rocks (fig. 3 ). Furthermore, the manganese occurs primarily as bementite, a manganese silicate that is difficult to refine. In comparison with manganese deposits elsewhere in the world (Dorr and others, 1973, p. 393), the deposits in the Wonder Mountain Roadless Area are small.

The only nonmetallic resource in the area is basalt, quarried locally for road base. An ample supply of basalt is available for this purpose outside the roadless area.

There has been no exploration for oil and $g$ as in the immediate vicinity of the Wonder Mountain Roadless Area. No oil and gas have been produced from wells drilled elsewhere on the Olympic Peninsula in rocks of similar age, type, and structural setting.

There is no indication of potential for any geothermal resource. 


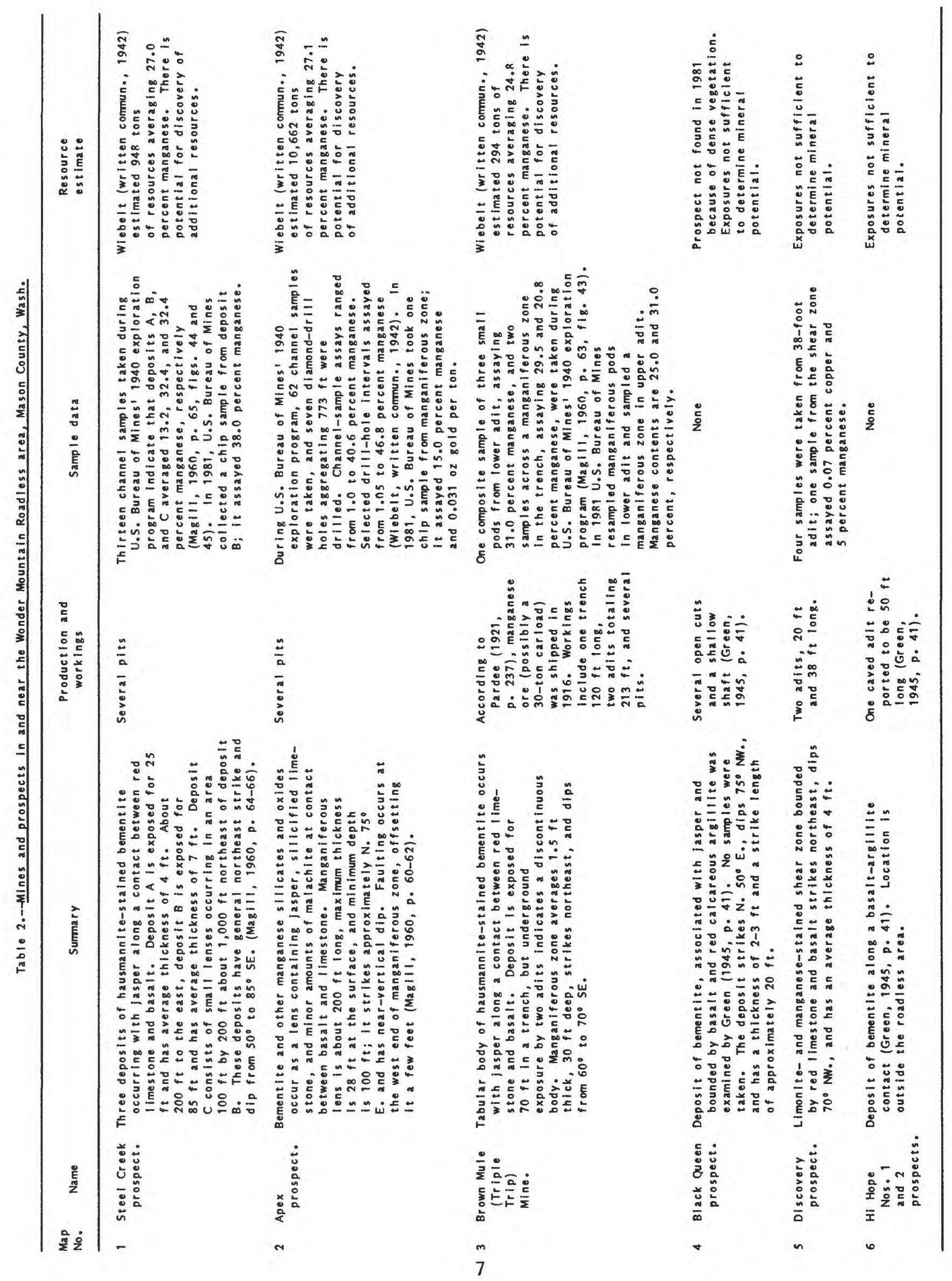




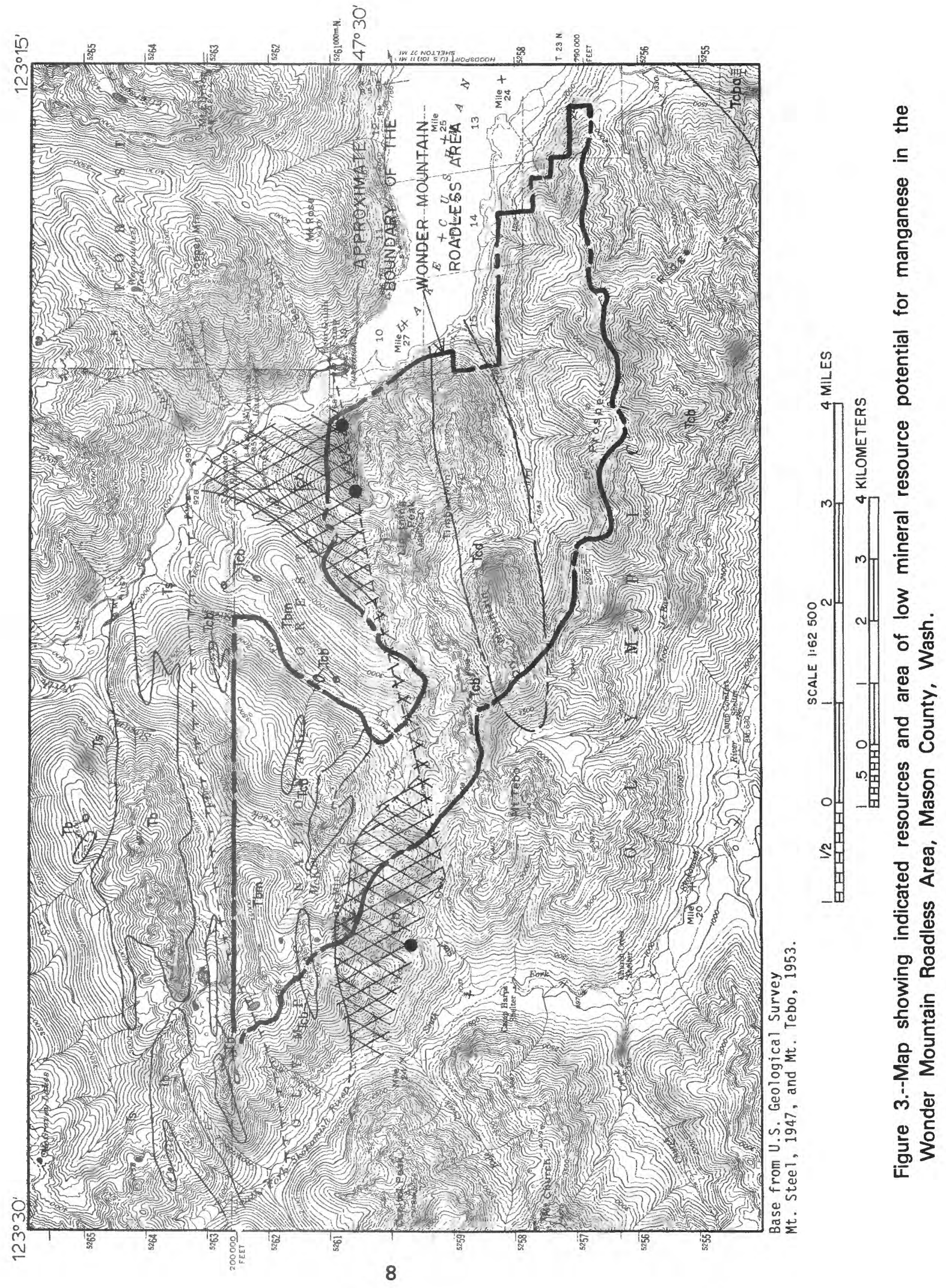




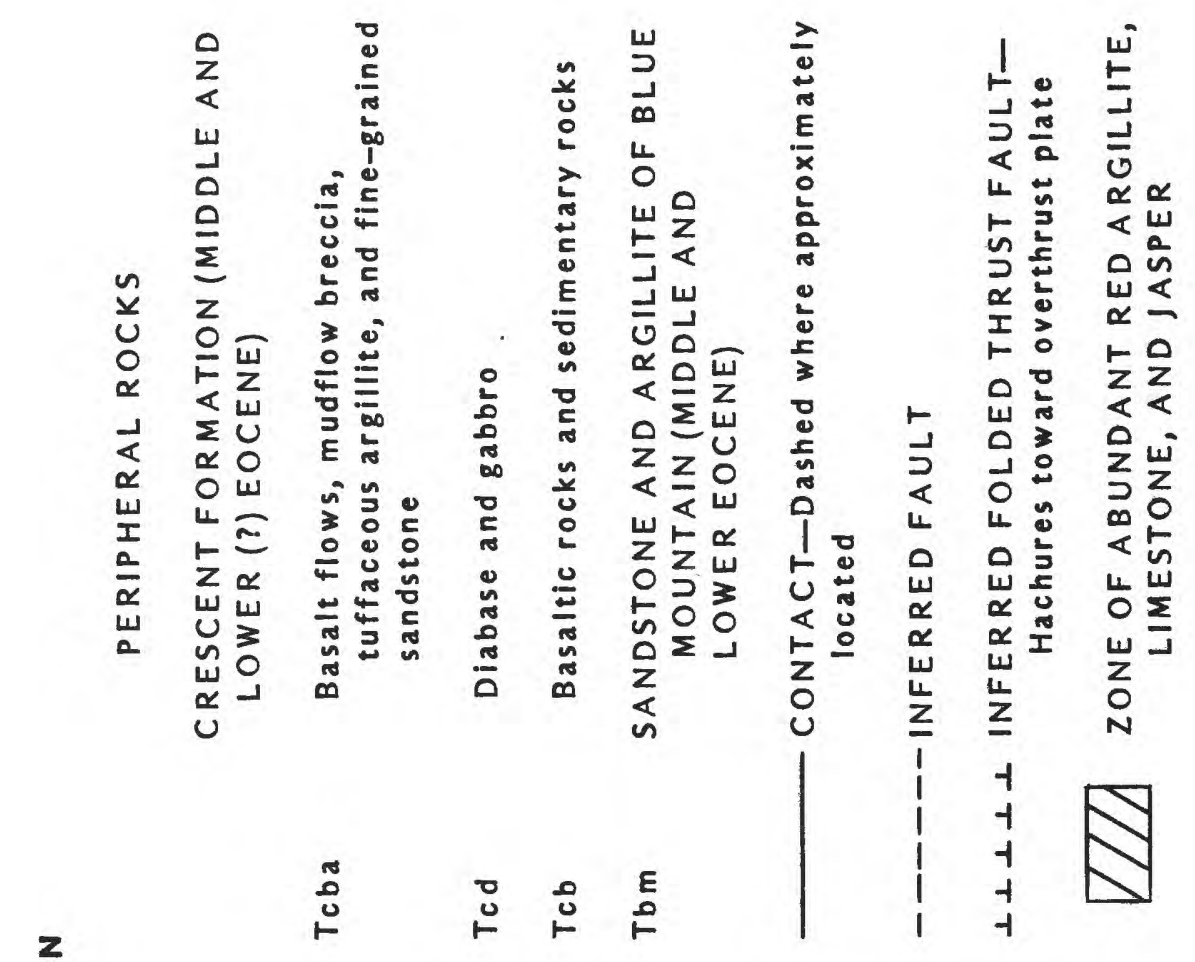

$z$
0
$\frac{2}{2}$
$z$
$\frac{1}{2}$
$\frac{1}{x}$
$w$

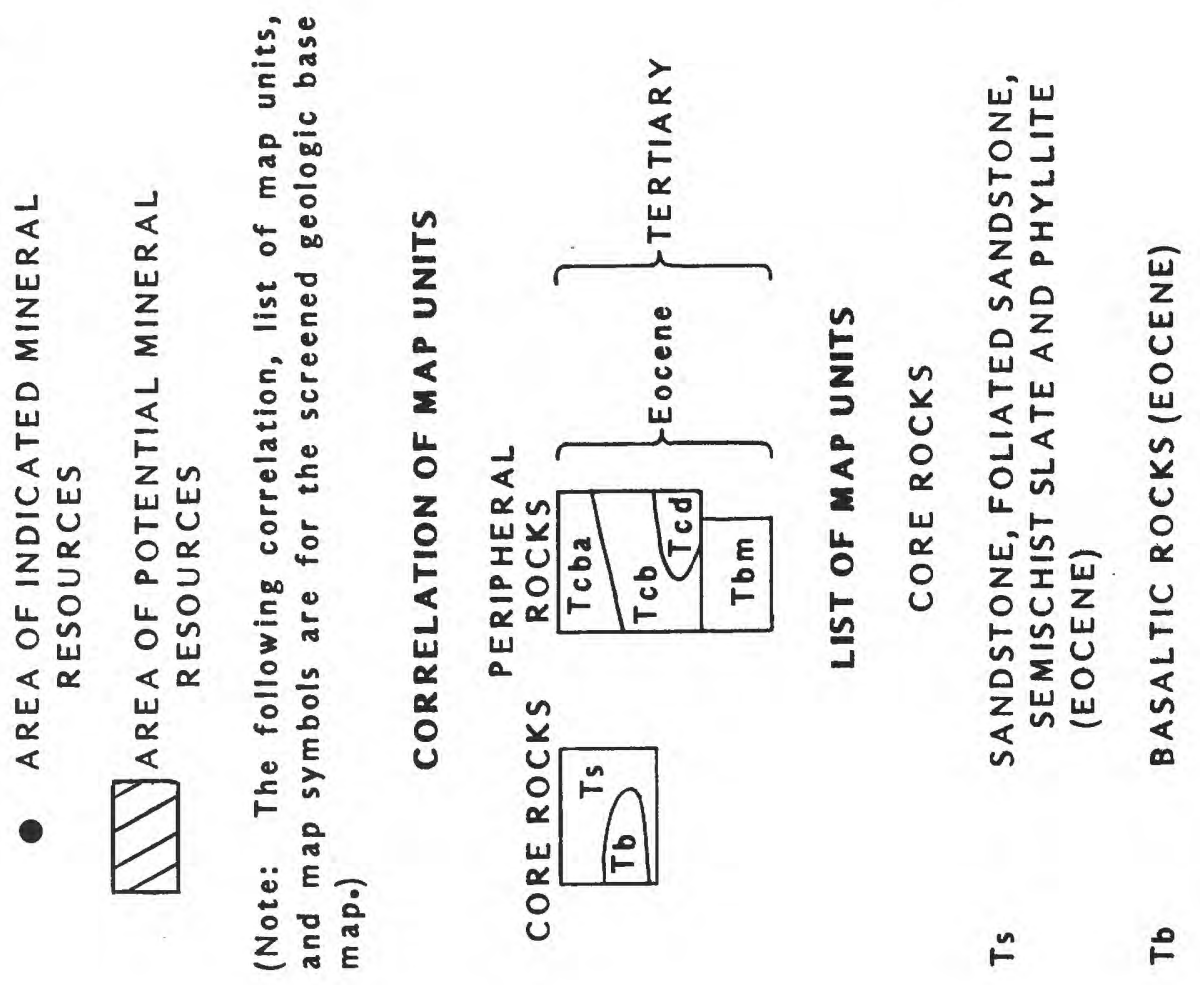




\section{SELECTED REFERENCES}

Cady, W. M., 1975, Tectonic setting of the Tertiary volcanic rocks of the Olympic Peninsula, Washington: U.S. Geological Survey Journal of Research, v. 3, no. 5, p. 573-582.

Cady, W. M., Sorensen, M. L., and MacLeod, N. S., 1972a, Geologic map of the Brothers quadrangle, Jefferson, Mason, and Kitsap Counties, Washington: U.S. Geological Survey Geologic Quadrangle Map GQ-969, scale 1:62,500.

Cady, W. M., Tabor, R. W., MacLeod, N. S., and Sorensen, M. L., 1972b, Geology of the Tyler Peak quadrangle, Clallam and Jefferson Counties, Washington: U.S. Geological Survey Geologic Quadrangle Map GQ-970, scale 1:62,500.

Church, S. E., Frisken, J. G., Mosier, E. L., and McDanal, S. K., 1982, Analytical results for stream sediments, panned concentrates from stream sediments, and rocks collected from the Wonder Mountain Roadless Area (06086), Washington: U.S. Geological Survey Open-File Report 82-1066, 84 p.

Dorr, J. V. No, II, Crittenden, M. D., Jre, and Worl, R. G., 1973, Manganese, in Brobst, D. A., and Pratt, W. P., eds., United States mineral resources: U.S. Geological Survey Professional Paper 820, p. 385-399.

Frisken, J. G., Church, S. E., Mosier, E. L., and McCollaum, A. D., in press, Geochemical map of the Wonder Mountain Roadless Area, Mason County, Washington: U.S. Geological Survey Miscellaneous Field Studies Map.

Garrison, R. E., 1973, Space-time relations of pelagic limestone and volcanic rocks, Olympic Peninsula, Washington: Geological Society of America Bulletin, v. 84, p. 583-594.

Green, S. H., 1945, Manganese deposits of the Olympic Peninsula, Washington: Washington Division of Mines and Mining Report of Investigations No. 7 , 45 p.

Grimes, D. J., and Marranzino, A. P., 1968, Directcurrent arc and alternating-current spark emission spectrographic field methods for the semiquantitative analysis of geologic materials: U.S. Geological Survey Circular 591, 6 p.

Iverson, $S_{0} R_{0}, 1982$, Mineral investigation of the Wonder Mountain RARE II Area (06086), Mason County, Washington: U.S. Bureau of Mines OpenFile Report MLA 105-82, 11 p.
Magill, E. A., 1960, Manganese deposits of the Olympic Peninsula, Washington: U.S. Bureau of Mines Report of Investigations $5530,82 \mathrm{p}$.

Overland, Larry, 1981, Early settlement of Lake Cushman: Belfair, Wash., Mason County Historical Society, $46 \mathrm{p}$.

Pardee, J. T., 1922, Deposits of manganese ore in Montana, Utah, Oregon, and Washington: U.S. Geological Survey Bulletin 725-C, p. 141-243.

Park, C. F., Jr., 1942, Manganese resources of the Olympic Peninsula, Washington-a preliminary report: U.S. Geological Survey Bulletin 931-R, p. 435-457.

1946, The spilite and manganese problems of the Olympic Peninsula, Washington: American Journal of Science, v. 244, no. 5, p. 305-323.

Rau, W. W., 1964, Foraminifera from the northern Olympic Peninsula, Washington: U.S. Geological Survey Professional Paper 374-G, P. G1-G33.

1967, Geology of the Wynoochee Valley quadrangle, Grays Harbor County, Washington: Washington Division of Mines and Geology Bulletin 56,51 p.

Roy, Supriya, 1981, Manganese deposits: New York, Academic Press, Inc., 458 p.

Sorem, R. K., and Gunn, D. W., 1967, Mineralogy of manganese deposits, Olympic Peninsula, Washington: Economic Geology, v. 62, p. 22-56.

Tabor, R. W., 1972, Age of the Olympic metamorphism, Washington-K-Ar dating of low-grade metamorphic rocks: Geological Society of America Bulletin, v. 83, p. 1805-1816.

1982, Geologic map of the Wonder Mountain Roadless Area, Mason County, Washington: U.S. Geological Survey Miscellaneous Field Studies Map MF-1418-A, scale 1:62,500.

Tabor, R. W., and Cady, W. M., 1978a, Geologic map of the Olympic Peninsula, Washington: U.S. Geological Survey Miscellaneous investigations Map I-994, scale $1: 125,000$.

$1978 \mathrm{~b}$. The structure of the Olympic Mountains, Washington-analysis of a subduction zone: U.S. Geological Survey Professional Paper 1033, 38 p.

Tabor, R. W., Yeats, R. S., and Sorensen, M. L., 1972, Geologic map of the Mount Angeles quadrangle, Clallam and Jefferson Counties, Washington: U.S. Geological Survey Quadrangle Map GQ-958, scale $1: 62,500$. 